\title{
PENINGKATAN KEMAMPUAN MEMECAHKAN MASALAH MELALUI PEMBELAJARAN THINK PAIR SQUARE SHARE BERBANTUAN LEMBAR PESAN BERMAKNA
}

\author{
Andi Navianto \\ SMP Negeri 3 Pule \\ andinavianto@gmail.com
}

\begin{abstract}
Abstrak
Peneliti sering menemukan siswa yang bingung memulai langkah awal dalam memecahkan masalah. Siswa kurang mampu menggunakan informasi yang tersedia dan pengetahuan yang telah dipelajari sebagai dasar menyelesaikan masalah. Selain itu, upaya siswa memecahkan masalah melalui diskusi dan menjalin komunikasi dengan siswa lain masih rendah. Penelitian ini bertujuan mendeskripsikan upaya meningkatkan kemampuan memecahkan masalah menggunakan Lembar Pesan Bermakna dalam pembelajaran kooperatif tipe Think Pair Square Share pada siswa kelas IX-A SMP Negeri 3 Pule tahun pelajaran 2017/2018. Subjek penelitian sebanyak 30 siswa. Penelitian tindakan kelas ini dilaksanakan sebanyak dua siklus. Masing-masing siklus terdiri dua pertemuan. Data yang dikumpulkan adalah lembar aktivitas siswa dan hasil tes. Tahap-tahap penelitian ini terdiri perencanaan, pelaksanaan, pengamatan, dan refleksi. Penggunaan Lembar Pesan Bermakna di dalam pembelajaran kooperatif tipe Think Pair Square Share (TPSS) dapat meningkatkan kemampuan memecahkan masalah pada siswa kelas IX-A SMP Negeri 3 Pule tahun Pelajaran 2017/2018. Hal ini ditunjukkan dengan adanya peningkatan hasil aktivitas dan tes siswa. Hasil aktivitas siswa mengalami peningkatan dari kategori Cukup pada siklus I menjadi kategori Baik pada siklus II. Hasil tes siswa menunjukkan peningkatan ketuntasan kelas dari $17 \%$ pada siklus I menjadi $87 \%$ pada siklus II dengan nilai rata-rata 79.
\end{abstract}

Kata kunci: kemampuan memecahkan masalah, pembelajaran kooperatif, TPSS

\begin{abstract}
Researchers often find students confused about starting the first step in solving problems. Students are less able to use the available information and knowledge that has been learned as a basis for solving problems. In addition, students' efforts to solve problems through discussion and establish communication with other students are still low. This study aims to describe efforts to improve problem-solving skills using Meaningful Message Sheets in Think Pair Square Share cooperative learning in class IX-A students of SMP Negeri 3 Pule in the $2017 / 2018$ school year. The research subjects were 30 students. This classroom action research has been carried out in two cycles. Each cycle consists of two meetings. The data collected were student
\end{abstract}

Dikirim : 2 September 2021, Diterima : 23 September 2021, Diterbitkan : 2 Oktober 2021 
activity sheets and test results. The stages of this research consist of planning, implementation, observation, and reflection. The use of Meaningful Message Sheets in Think Pair Square Share (TPSS) cooperative learning can improve problem solving skills in class IX-A students of SMP Negeri 3 Pule in the 2017/2018 academic year. This is indicated by an increase in student activity and test results. The results of student activities have increased from the Enough category in the first cycle to the Good category in the second cycle. Student test results showed an increase in class completeness from $17 \%$ in the first cycle to $87 \%$ in the second cycle with an average score of 79 .

Keywords: problem solving skills, cooperative learning, TPSS

\section{PENDAHULUAN}

Kemampuan memecahkan masalah merupakan salah satu kemampuan yang harus dimiliki setiap orang. Kemampuan ini menjadi bekal yang penting bagi seseorang untuk menghadapi kemajuan dan perkembangan jaman. Menurut (Wardhani, 2008) memecahkan masalah merupakan kegiatan penerapan pengetahuan yang dimiliki seseorang sebelumnya ke dalam situasi baru yang belum dikenal. Masalah yang akan dihadapi siswa di masa akan datang sering tidaklah sama dengan masa lampau maupun masa sekarang. Masalah yang datang akan lebih komplek dan berbeda masingmasing orang.

Oleh karena itu, setiap orang harus dibekali pola berpikir dalam menyelesaikan masalah. Setiap orang harus mampu mengindetifikasi masalah yang sedang mereka hadapi. Setiap orang harus mampu menentukan masalah yang akan mereka selesaikan dan kemudian menyusun langkah-langkah penyelesaian. Dalam menyusun langkah penyelesaian, setiap orang harus menyadari sumber daya atau kekuatan yang dia miliki dan informasi apa yang telah diketahui atau yang tersedia

Kemampuan memecahkan masalah merupakan menjadi salah satu kemampuan yang dikuasai siswa setelah mendapatkan pembelajaran matematika (Effendi, 2012). Namun dalam praktiknya, peneliti sering menemui siswa kesulitan dalam menyelesaikan masalah yang biasanya berbentuk soal cerita. Siswa tidak tepat dalam menyebutkan atau menulis pertanyaan yang harus dijawab. Siswa juga kurang mampu menggunakan informasi yang ada di soal untuk menjawab. Banyak siswa yang kurang mampu menerapkan pengetahuan yang telah dipelajari dalam penyelesaian masalah. Selain itu, upaya siswa memecahkan masalah melalui diskusi dan menjalin komunikasi dengan siswa lain masih rendah.

Model pembelajaran ini yang dapat digunakan untuk membangun interaksi antar siswa dan juga mendorong kemandirian siswa dalam belajar 
adalah pembelajaran kooperatif tipe Think Pair Square Share (TPSS). Kemandirian sangat perlu ditumbuhkembangkan di siswa supaya tidak selalu tergantung dengan orang lain ketika menghadapi masalah. Penelitian (Jumarni, dkk., 2014) menunjukkan melalui pembelajaran kooperatif tipe Think Pair Square siswa lebih mampu mengeluarkan ide penyelesaian masalah berupa pemahaman konsep maupun penerapan dalam situasi nyata. Menurut (Sumaryati dan Sumarmo, 2013) melalui pembelajaran tipe TPSS siswa diberi kesempatan bekerja secara mandiri pada langkah Think. Siswa pun difasilitasi bekerja sama dengan siswa lain pada langkah Pair dan Square. Hasil belajar yang diperoleh siswa yang menggunakan model cooperatif learning tipe Think Pair Square lebih tinggi dibandingkan siswa yang mengalami pembelajaran kovnesional (Wara, dkk., 2012)

Dalam pemecahan masalah, siswa mengalami kesulitan menerapkan pengetahuan yang dimiliki pada situasi atau masalah yang diberikan. Siswa tidak tahu dari mana siswa harus memulai menjawab. Peneliti juga melihat siswa yang sudah menjawab merasa yakin atau puas terhadap jawaban yang telah dia berikan sehingga siswa tidak merasa perlu mengecek kembali kebenaran jawabannya. Setelah dicek ternyata jawabannya belum menjawab masalah yang diberikan. Agar siswa dapat memecahkan masalah lebih baik dapat dibantu dengan mengikuti langka-langkah Polya. Menurut (Zahriah, dkk., 2016) pemecahan masalah menggunakan model Polya menghasilkan kemampuan analisis dan hasil belajar siswa lebih tinggi dari pada dengan pembelajaran konvensional. Selain itu, terjadi peningkatan aktivitas siswa dan cara berpikir yang lebih terstruktur dalam memecahkan masalah.

Berdasarkan uraian di atas maka peneliti melakukan penelitian berjudul "Upaya Meningkatkan Kemampuan Memecahkan Masalah Menggunakan Lembar Pesan Bermakna dalam Pembelajaran Kooperatif tipe Think Pair Square Share". Penelitian ini bertujuan mendeskripsikan upaya meningkatkan kemampuan memecahkan masalah menggunakan Lembar Pesan Bermakna dalam pembelajaran kooperatif tipe Think Pair Square Share pada siswa kelas IX-A SMP Negeri 3 Pule tahun pelajaran 2017/2018. Penelitian dilakukan pada siswa kelas IX-A karena perbedaan kemampuan memecahkan masalah sangat mencolok. Peneliti menggunakan Lembar Pesan Bermakna untuk membantu siswa menyelesaikan masalah berdasarkan langkah Polya.

Menurut (Uno, 2011) salah satu tipe belajar adalah memecahkan masalah. Menurut (Turmudi, 2009) pemecahan masalah menjadi bagian penting dalam pembelajaran matematika. Menurut (Stone, 2009) pemecahan masalah matematika menjadi bagian yang tidaklah mudah dalam pembelajaran. Kemampuan memecahkan masalah sangat penting untuk 
dimiliki setiap siswa. Pendidik harus mengupayakan terbangunnya kemampuan itu di siswa walau hal ini bukan hal yang mudah. Dalam memecahkan masalah bukan sekedar menjawab tapi juga menurut (Sumiati dan Asra, 2012) harus memenuhi aturan-aturan yang lebih tinggi. Proses pemecahan masalah memberikan kesempatan kepada siswa untuk terlibat aktif dalam mempelajari, mencari dan menemukan sendiri informasi untuk diolah menjadi konsep, prinsip, teori atau kesimpulan.

Kegiatan pemecahan masalah dapat dilakukan menggunakan langkahlangkah Polya. Langkah Polya terdiri dari memahami masalah, menentukan rencana strategi penyelesaian, melaksanakan strategi penyelesaian, dan memeriksa Menurut (Komariah, 2011) ada empat langkah Polya, yaitu memahami masalah, menentukan rencana strategi penyelesaian masalah, menyelesaikan strategi penyelesaian masalah, dan memeriksa kembali jawaban yang diperoleh. Kemampuan memecahkan masalah dapat dilihat dari kemampuan siswa dalam mengidentifikasi masalah yang harus dijawab, menemukan fakta atau informasi yang ada dan informasi yang dibutuhkan untuk diolah dengan pengetahuan yang dia miliki dalam rangka menemukan jawaban. Siswa harus mampu menyusun langkah-langkah penyelesaian dan alternatifnya kemudian menerapkan pengetahuannya untuk mendapatkan jawaban masalah. Setelah menemukan jawabannya, siswa harus melakukan pengecekan kebenaran jawaban.

Agar siswa terbiasa melakukan memecahkan masalah maka perlu dilakukan pembelajaran yang tepat. Menurut (Daryanto, 2013) pembelajaran merupakan suatu proses penciptaan lingkungan atau situasi terjadinya proses belajar. Menurut (Hamalik, 2009), belajar merupakan perubahan perilaku individu akibat pengalaman yang dialami inidividu tersebut. Menurut (Abdurrahman dan Mulyono, 2009) melalui pengalaman danlatihan, seseorang mengalami proses belajar sehingga terjadi perubahan tingkah laku. Dari proses belajar yang dilakukan akan didapatkan hasil belajar. Menurut (Sudjana, 2010), proses belajar yang dilakukan akan menghasilkan kemampuan. Artinya seorang individu setelah mengalami proses belajar akan memiliki kemampuan. Individu yang awalnya tidak mampu menjadi lebih mampu, dari tidak bisa menjadi bisa, dari tidak tahu menjadi tahu.

Pembelajaran kooperatif sering diartikan sebagai kerja kelompok. Menurut (Isjoni, 2008) pembelajaran kooperatif menggunakan kelompok sebagai sarana siswa untuk saling membantu dalam menyelesaikan sesuatu. Menurut (Taniredja, dkk., 2012) melalui pembelajaran kooperatif siswa diberi kesempatan untuk saling bekerja sama dengan tugas-tugas yang terstruktur. Salah satu tipe pembelajaran kooperatif adalah Think Pair Square 
Share (TPSS). Di awal kegiatan TPSS, siswa diharuskan menyelesaikan masalah secara mandiri. Dengan hasil mandiri itu siswa menjadikan sebagai bahan dalam diskusi secara berpasangan dan berkelompok.

Langkah-langkah pembelajaran TPSS dijelaskan (Grinham, 2009) secara berurutan adalah Think, Pair, Square, dan Share. Pada langkah Think, siswa diberikan kesempatan berpikir dan menemukan jawaban masalah atau pertanyaan yang diberikan secara mandiri tanpa berdiskusi dengan siswa lain. Langkah Pair, siswa mulai bekerja secara berpasangan untuk mendiskusikan dan menghasilkan jawaban atas dasar jawaban masingmasing siswa di langkah Think. Selanjutnya di langkah Square, pasangan siswa di langkah Pair berkumpul dengan pasangan lain sehingga kelompok diskusi yang awalnya beranggotakan dua orang menjadi empat orang. Siswa berdiskusi untuk menyepakati jawaban pertanyaan atau masalah yang diberikan guru. Hasil ini merupakan jawaban kelompok yang akan disampaikan pada langkah selanjutnya. Pada langkah terakhir Share, guru dapat meminta perwakilan kelompok untuk melaporkan hasil kelompoknya. Lalu dibuat kesimpulan atas dasar hasil semua kelompok.

Untuk membantu siswa dalam meningkatan kemampuan memecahkan masalah maka peneliti membuat alat bantu yang diberi nama Lembar Pesan Bermakna. Alat bantu ini digunakan dapat setiap tahapan pembelajaran kooperatif tipe TPSS. Melalui alat bantu ini, siswa diarahkan agar dapat menunjukkan informasi yang termuat di permasalahan dan menemukan pertanyaan yang harus dijawab. Lalu siswa dapat menggali konsep dan pengetahuan yang dimiliki siswa dan menghubungkan informasi yang tersedia dalam rangka menjawab permasalahan yang diberikan. Ide penyusunan Lembar Pesan Bermakna oleh penulis terinspirasi dari langkah Polya dalam pemecahan masalah atau problem solving. Jadi dalam langkah Polya, siswa harus memahami masalah yang akan diselesaikan. Kemudian siswa membuat rencana penyelesaian dan menyelesaikan masalah sesuai rencana yang telah disusun. Di langkah selanjutnya siswa harus mampu meyakinkan bahwa jawaban yang diberikan siswa adalah benar.

Lembar Pesan Bermakna ini berupa selembar kertas yang memuat kolom atau bagian-bagian yang nantinya akan diisi siswa. Ada dua kata kunci dalam alat ini yaitu Pesan dan Bermakna. Pesan dapat diartikan dua hal, yaitu arti sebenarnya dan sebagai singkatan dari pengorganisasian. Pesan berarti sesuatu, kata atau kalimat yang memuat informasi-informasi yang harus ditangkap siswa dalam proses penyelesaian masalah. Pesan sebagai pengorganisasian bermakna lembar ini digunakan untuk membantu siswa mengorganisasikan ide-idenya dalam memecahkan masalah. Sedang Bermakna maksudnya membantu siswa untuk menghubungkan pengetahuan 
atau konsep yang dimiliki siswa dan informasi-informasi yang diperoleh siswa dari soal yang diberikan dalam rangka memecahkan masalah.

\section{LEMBAR PESAN BERMAKNA}

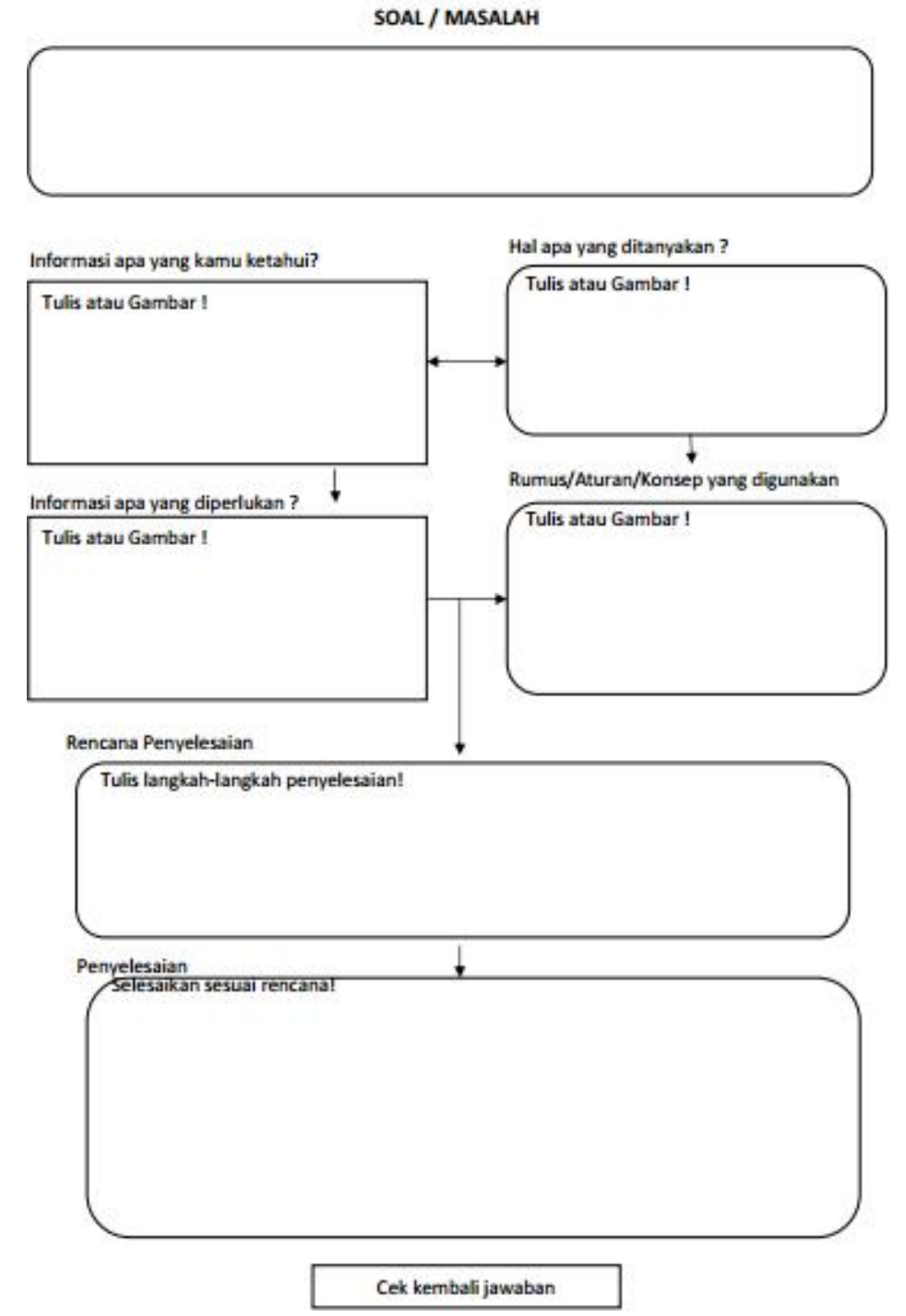

Gambar 1. Lembar Pesan Bermakna

\section{METODE PENELITIAN}

Penelitian ini dilaksanakan pada semester ganjil tahun pelajaran 2017/2018. Subjek penelitiannya adalah siswa kelas IX-A SMP Negeri 3 Pule sebanyak 30 siswa. Penelitian tindakan kelas ini dilaksanakan sebanyak dua siklus. Masing-masing siklus terdiri dua pertemuan. Data yang dikumpulkan adalah lembar aktivitas siswa dan hasil tes. 
Tahap-tahap penelitian ini mengikuti model Kemmis dan Mc Taggart dalam (Arikunto, 2008), yaitu: perencanaan, pelaksanaan tindakan, pengamatan, dan refleksi. Kegiatan yang peneliti lakukan pada tahap perencanaan adalah merancang dan menyusun RPP berdasarkan Silabus yang ada, Lembar Pesan Bermakna dan masalah-masalahnya, lembar pengamatan, soal tes evaluasi, merancang pembagian kelompok, dan mencari masukan untuk penelitian selanjutnya. Peneliti melaksanakan tahap perencanaan pada tahap pelaksanaan. Kegiatan pembelajaran kooperatif tipe TPSS terdiri kegiatan pendahuluan, inti, dan penutup.

Pengamatan dilakukan selama pembelajaran berlangsung. Peneliti menentukan indikator-indikator sebagai dasar menilai aktivitas siswa. Aktivitas siswa diberi skor pada lembar pengamatan yang telah disiapkan. Indikator yang disusun mencerminkan aktivitas siswa dalam pembelajaran kooperatif TPSS. Indikator langkah Think terdiri siswa mencermati dan berusaha menyelesaikan masalah. Pada langkah Pair dilihat keaktifan siswa dalam menyampaikan pendapat dan tetap bersama pasangannya. Di langkah Square, guru memantau keaktifan siswa dalam berdiskusi dengan kelompoknya dan tetap bersama kelompoknya. Sedang pada langkah Share guru dapat menilai keaktifan siswa dalam mempresentasikan hasil kelompoknya atau memperhatikan presentasi kelompok lain dan memberi tanggapan. Selanjutnya peneliti melakukan evaluasi terhadap pelaksanaan pembelajaran di tahap refleksi berdasarkan hasil pengamatan aktivitas dan tes siswa. Peneliti mendata permasalahan yang muncul dan tindakantindakan yang telah dilakukan. Lalu peneliti melakukan analisis bersama teman sejawat dan menentukan perbaikan yang akan dilaksanakan.

Analisis data penelitian dilakukan terhadap data aktivitas siswa dan hasil tes siswa. Data aktivitas siswa dijumlahkan skornya berdasarkan masing-masing langkah TPSS lalu dijadikan persentase dengan rumus sebagai berikut:

$$
\text { Persentase Aktivitas Siswa (PAS) }=\frac{\text { Jumlah Skor }}{\text { Skor Maksimal }} \times 100 \%
$$

Lalu persentase aktivitas siswa dicari Presentase Rata-rata (PR) sebagai dasar menentukan kategori aktivitas siswa sebagai berikut:

$$
\begin{array}{ll}
85 \% \leq \mathrm{PR} \leq 100 \% & \text { : Sangat Baik } \\
70 \% \leq \mathrm{PR}<85 \% & \text { : Baik } \\
55 \% \leq \mathrm{PR}<70 \% & \text { : Cukup } \\
40 \% \leq \mathrm{PR}<55 \% & \text { : Kurang } \\
0 \% \leq \mathrm{PR}<40 \% & \text { : Sangat Kurang }
\end{array}
$$

(sumber: Sukardi, 2008:146) 
Hasil tes siswa yang telah diberi skor sesuai pedoman penilaian digunakan untuk menilai persentase ketuntasan kelas. Ketuntasan kelas dicapai jika 80\% siswa mendapat nilai minimal KKM. Nilai KKM yang digunakan sesuai yang telah ditentukan di SMP Negeri 3 Pule adalah 70.

Tingkat keberhasilan suatu siklus yang ditetapkan pada penelitian adalah hasil aktivitas siswa siswa minimal di kategori Baik dan ketuntasan kelas tercapai. Jika suatu siklus tidak memenuhi tingkat keberhasilan maka akan dilanjutkan ke siklus berikutnya.

\section{HASIL DAN PEMBAHASAN}

Tindakan dalam penelitian ini dilaksanakan sebanyak dua siklus. Tiap siklus terdiri dua pertemuan. Alokasi waktu tiap pertemuan adalah 2 X 40 menit. Secara umum langkah-langkah pembelajarannya sebagai berikut:

1. Siswa dibuat berpasangan. Lalu dibuat kelompok yang terdiri dari dua pasangan. Namun ada satu kelompok yang terdiri dari tiga pasangan. Pembuatan pasangan dan kelompok ini bertujuan agar terjadi proses diskusi, berbagi pengetahuan dan ide dalam menyelesaikan masalah.

2. Guru membagikan Lembar Pesan Bermakna kepada setiap siswa. Lalu memberikan penjelasan penggunaan Lembar ini.

3. Setelah dirasa dipaham penggunaan Lembar Pesan Bermakna, siswa diberikan soal yang berisi masalah. Pada langkah Think ini siswa harus berusaha menyelesaikan masalah secara mandiri menggunakan Lembar Pesan Bermakna tanpa bertanya atau berdiskusi dengan siswa lain selama 15 menit.

4. Selanjutnya di langkah Pair, siswa diminta untuk berdiskusi tentang jawaban dalam Lembar Pesan Bermakna yang telah mereka dapatkan dan mendiskusikan jawaban yang mereka sepakati selama 20 menit.

5. Kegiatan selanjutnya langkah Square. Pasangan siswa berkumpul dengan pasangan siswa lainnya sesuai pembagian kelompok di awal pembelajaran. Selama 20 menit siswa terlibat dalam diskusi kelompok untuk menyepakati jawaban kelompok dan membuat laporan yang akan dipresentasikan dalam diskusi kelas.

6. Langkah selanjutnya adalah Share dimana dilakukan presentasi kelompok. Di langkah ini siswa melaporkan hasil kelompoknya di depan kelas. Siswa lain memperhatikan presentasi dan menanggapi setelah peresentasi selesai.

7. Bersama guru, siswa membuat kesimpulan atas diskusi dan pembelajaran yang telah mereka lakukan.

Adapun kekurangan dalam pelaksanaan tindakan siklus I dari hasil 
refleksi sebagai berikut:

a. Ada siswa yang tidak terlalu memberikan respon atas penjelasan yang telah disampaikan guru.

b. Sebagian siswa ternyata belum memahami cara menggunakan Lembar Pesan Bermakna.

c. Pada saat langkah Think, peneliti masih menemui beberapa siswa yang belum mandiri dalam mengerjakan soal secara individu. Siswa itu berusaha untuk bertanya dan mengajak diskusi siswa lain.

d. Sebagian siswa belum terlibat aktif berdiskusi baik saat langkah Pair maupun Square. Hanya menyerahkan hasil kelompok pada temannya. Beberapa siswa malah tidak berada di kelompoknya.

e. Presentasi kelompok ternyata membutuhkan waktu yang lama karena siswa menuliskan hasil kelompoknya di papan tulis baru menyampaikan secara lisan.

f. Aktivitas siswa masih dalam kategori Cukup ditunjukkan Tabel 1 dan hasil tes yang diperoleh siswa juga belum memuaskan ditunjukkan Tabel 2 di bawah ini.

Tabel 1. Hasil Aktivitas Siswa Siklus I

\begin{tabular}{lcc}
\hline \multicolumn{2}{l}{ Aktivitas yang diamati } & Persentase Aktivitas Siswa \\
\hline A & Think & 75 \\
\hline B & Pair & 63 \\
\hline C & Square & 63 \\
\hline D & Share & 53 \\
\hline Presentase Rata-rata & 64 \\
\hline & Kategori & Cukup \\
\hline & Tabel 2. Hasil Tes Siswa Siklus I \\
\hline Uraian & Nilai \\
\hline & 12 \\
\hline & Nilai Terendah & 100 \\
\hline Nilai Tertinggi & 52 \\
\hline Nilai rata-rata & $17 \%$ \\
\hline
\end{tabular}

Karena siklus I belum mencapai tingkat keberhasilan yang telah ditetapkan maka pembelajaran dilanjutkan siklus II. Pada siklus II dilakukan perbaikan-perbaikan sebagai berikut:

a. Memberikan pertanyaan kepada siswa yang kurang perhatian tentang apa yang telah dijelaskan guru.

b. Memberikan penjelasan lebih dalam dengan memberi contoh cara 
menggunakan Lembar Pesan Bermakna

c. Agar siswa siswa lebih aktif diskusi dan bekerja sama, guru senantiasa mengingatkan semua siswa bahkan menyebutkan siswa-siswa tertentu untuk terlibat aktif bersama kelompoknya.

d. Pada siklus II, metode presentasi dibuat berbeda daripada siklus I. Guru meminta siswa menyiapkan bahan presentasi dari rumah. Hasil kelompok dapat ditulis di kertas karton yang nantinya dapat ditempel untuk dipresentasikan di depan kelas.

e. Guru perlu memberi lebih dari satu soal untuk diselesaikan siswa agar pengalaman siswa lebih banyak sehingga akan membantu siswa untuk menyelesaikan tes.

Berdasarkan hasil pengamatan pembelajaran yang dilakukan di siklus II didapatkan perbaikan aktivitas dan tes siswa yang ditunjukkan Tabel 3 dan Tabel 4 di bawah ini.

Tabel 3. Hasil Aktivitas Siswa Siklus II

\begin{tabular}{lcc}
\hline \multicolumn{2}{l}{ Aktivitas yang diamati } & Persentase Aktivitas Siswa \\
\hline A & Think & 95 \\
\hline B & Pair & 87 \\
\hline C & Square & 73 \\
\hline D & Share & 70 \\
\hline \multicolumn{2}{c}{ Persentase Rata-rata } & 81 \\
\hline \multicolumn{3}{r}{ Kategori } \\
\hline
\end{tabular}

Tabel 4. Hasil Tes Siswa Siklus II

\begin{tabular}{cc}
\hline Uraian & Nilai \\
\hline Nilai Terendah & 64 \\
\hline Nilai Tertinggi & 100 \\
\hline Nilai Rata-rata & 79 \\
\hline Ketuntasan Kelas & $87 \%$ \\
\hline
\end{tabular}

Hasil dari Siklus II didapatkan bahwa aktivitas siswa termasuk kategori Baik dan 87\% siswa telah tuntas dengan nilai rata-rata 79. Karena pembelajaran siklus II telah memenuhi tingkat keberhasilan maka pembelajaran telah memenuhi indikator keberhasilan penelitian maka pembelajaran tidak dilanjutkan siklus selanjutnya.

Berdasarkan hasil siklus I dan II diperoleh penggunaan Lembar Pesan Bermakna dalam pembelajaran kooperatif tipe TPSS dapat meningkatkan 
Upaya Meningkatkan Kemampuan Memecahkan Masalah Menggunakan Lembar Pesan Bermakna Dalam Pembelajaran Kooperatif Tipe Think Pair Square Share

kemampuan memecahkan masalah. Hal ini ditunjukkan peningkatan hasil tes siswa kelas IX-A SMP Negeri 3 Pule yang disajikan Tabel 5.

Tabel 5. Peningkatan Kemampuan Memecahkan Masalah

\begin{tabular}{ccc}
\hline Tahap & Nilai Rata-rata & Ketuntasan Kelas \\
\hline Siklus I & 52 & $17 \%$ \\
\hline Siklus II & 79 & $87 \%$ \\
\hline
\end{tabular}

Dilihat dari nilai rata-rata dan ketuntasan kelas menunjukkan peningkatan dari siklus I ke siklus II. Hal ini menunjukkan bahwa siswa melakukan proses belajar karena siswa yang awalnya belum mampu menjadi mampu. Melalui latihan, menurut (Abdurrahman dan Mulyono, 2009), siswa mengalami proses belajar, menjadikan siswa mengalami perubahan kemampuan. Menurut (Sudjana, 2010) siswa memiliki kemampuan setelah menerima pengalaman belajar.

Tabel 6. Peningkatan Aktivitas Siswa

\begin{tabular}{ccccc}
\hline \multicolumn{2}{c}{ Aktivitas Siswa yang Diamati } & Siklus I & Siklus II & Peningkatan \\
\hline A & Think & $75 \%$ & $95 \%$ & $20 \%$ \\
\hline B & Pair & $63 \%$ & $87 \%$ & $24 \%$ \\
\hline C & Square & $63 \%$ & $73 \%$ & $10 \%$ \\
\hline D & Share & $53 \%$ & $70 \%$ & $17 \%$ \\
\hline \multicolumn{2}{c}{ Persentase Rata-rata } & $64 \%$ & $81 \%$ & $18 \%$ \\
\hline & Kategori & Cukup & Baik & \\
\hline
\end{tabular}

Berdasarkan Tabel 7 dapat dilihat terjadi peningkatan aktivitas siswa siklus II dibanding siklus I. Hal ini menunjukkan perubahan aktivitas siswa yang lebih baik. Perubahan aktivitas terjadi pada semua langkah pembelajaran TPSS. Terjadi perubahan dalam hal kemandirian, diskusi dan kerjasama siswa secara lebih baik. Menurut (Isjoni, 2008) pembelajaran kooperatif menggunakan kelompok sebagai sarana siswa untuk saling membantu dalam menyelesaikan sesuatu. (Taniredja, dkk., 2012) juga mengungkapkan tujuan belajar dapat diperoleh lebih baik melalui pembelajaran kooperatif yang memberikan kesempatan siswa untuk bekerjasama.

\section{KESIMPULAN DAN SARAN}

Penggunaan Lembar Pesan Bermakna di dalam pembelajaran kooperatif tipe Think Pair Square Share (TPSS) dapat meningkatkan 
kemampuan memecahkan masalah pada siswa kelas IX-A SMP Negeri 3 Pule tahun Pelajaran 2017/2018. Hal ini ditunjukkan hasil aktivitas dan tes siswa. Hasil aktivitas siswa mengalami peningkatan dari kategori Cukup pada siklus I menjadi kategori Baik pada siklus II. Hasil tes siswa menunjukkan peningkatan ketuntasan kelas dari $17 \%$ pada siklus I menjadi $87 \%$ pada siklus II dengan nilai rata-rata 79.

Pembelajaran kooperatif tipe Think Pair Square Share (TPSS) dapat dijadikan alternatif untuk meningkatkan kemampuan memecahkan masalah. Penggunaan Lembar Pesan Bermakna dapat menjadi alat bantu untuk memberi pedoman dalam menyelesaikan masalah. Guru dapat menggunakan isian siswa dalam Lembar Pesan Bermakna untuk memperbaiki pemahaman konsep siswa. Namun Lembar Pesan Bermakna ini perlu perbaikan. Pada kegiatan terakhir Cek Kembali Jawaban belum muncul kegiatan siswa secara tertulis dalam meninjau kembali kebenaran jawaban yang telah didapatkan siswa.

\section{DAFTAR RUJUKAN}

Abdurrahman dan Mulyono. 2009. Pendidikan Bagi Anak Berkesulitan Belajar. Jakarta: Rineka Cipta

Arikunto, S. 2008. Penelitian Tindakan Kelas. Jakarta: Bumi Aksara.

Daryanto. 2013. Media Pembelajaran. Yogyakarta: Gava Media

Effendi, S. 2012. Metode Penelitian Survei. Jakarta: LP3ES

Grinham, G. 2009. Think-Pair-Square-Share. [online]. Tersedia: http://www.slideshare.net/greg4758/think-pair-square-share

Hamalik, 0. 2009. Psikologi Belajar dan Mengajar. Bandung: PT Sinar Baru Algensindo

Isjoni. 2008. Pembelajaran Kooperatif. Yogyakarta: Pustaka Belajar

Jumarni, Pasaribu, M., \& Lamba, H.A. 2014. Pengaruh Model Pembelajaran Kooperatif Tipe Think Pair Square terhadap Pemahaman Konsep pada pokok bahasan Usaha dan Energi Siswa Kelas VIII SMP Negeri 9 Palu. Jurnal Pendidikan Fisika Tadulako (JPFT), 2(1)

Komariah, K. 2011. Penerapan Metode Pembelajaran Problem Solving Model Polya Untuk Meningkatkan Kemampuan Memecahkan Masalah Bagi Siswa Kelas IX-J di SMPN 3 Cimahi. ProsidingSeminar Nasional Penelitian, Pendidikan dan Penerapan MIPA, Fakultas MIPA, Universitas Negeri Yogyakarta, 14 Mei 2011

Stone, R. 2009. Cara-cara Terbaik Mnegajarkan Matematika. Jakarta: Indeks Sudjana, N. 2010. Penilaian Hasil Proses Belajar Mengajar. Bandung: PT. Remaja Rosdakarya

Sumaryati dan Sumarmo. 2013. Pendekatan Induktif-Deduktif Disertai Strategi Think-Pair-Square-Share Untuk Meningkatkan Kemampuan Pemahaman dan Berpikir Kritis Serta Disposisi Matematis Siswa SMA. 
Jurnal Ilmiah Program Studi Matematika STKIP Siliwangi Bandung, 2(1)

Sumiati dan Asra. 2012. Metode Pembelajaran. Bandung: CV Wacana Prima

Taniredja, dkk. 2012. Model-model Pembelajarn Inovatif. Bandung: ALFABETA

Turmudi. 2009. Landasan Filosofis dan Teoritis Pembelajaran Matematika. Jakarta: Leuser Cipta Pustaka

Wara J, M., Rizal, Y., \& Nilawasti. 2012. Model Coopertive Learning Tipe Think Pair Square dalam Pembelajaran Matematika di Kelas VII SMPN 1 Pulau Punjung. Jurnal Pendidikan Matematika, 1(1), 35-38

Wardhani, S. 2008. Analisis SI dan SKL Mata Pelajaran Matematika SMP/MTS untuk Optimalisasi Tujuan Mata Pelajaran Matematika: Yogyakarta: PPPPTK

Uno, H. B. 2011. Perencanaan Pembelajaran. Jakarta: PT Bumi Aksara

Zahriah, Hasan, M., \& Jalil, Z. 2016. Penerapan Pemecahan Masalah Model Polya untuk Meningkatkan Kemampuan Analisis dan Hasil Belajar pada Materi Vektor di SMAN 1 Darul Imarah. Jurnal Pendidikan Sains Indonesia, 4(2), 151-161 